\title{
ANALISIS SPASIAL PERUBAHAN AREA TERBANGUN KOTA GORONTALO Spatial Analysis Of Gorontalo City Building Area Changes
}

\author{
Muhammad Rijal Syukri ${ }^{1}$, Sri Sutarni Arifin ${ }^{2}$ \\ 1,2Universitas Negeri Gorontalo, Indonesia \\ Email Korespondensi: muh.rijalsyukri@gmail.com
}

DOI: http://dx.doi.org/10.31314/jsig.v1i2.181

\begin{abstract}
Development in urban areas growth accompanied by increasing population. This increase has an impact on the increasing need for urban space. This causes the area to be built in urban areas to increase and the reduction of open space so as to encourage the use of rice fields as residential areas and offices. Therefore it is necessary to do a study or evaluation through spatial analysis to determine changes in the use of paddy fields in Gorontalo City in a certain period of time. This study is one of the references in the direction of environmentally sound development for the future. This study aims to analyze changes in land use as a built area within 5 years from 2008 to 2013. The method used in this study is spatial analysis consisting of image data and digital maps as supporting data. The analysis was carried out by overlaying the land use map technique with different periods of time from the interpretation of digital satellite images. The results showed that there were two types of changes in the built-up area in Gorontalo City within a period of 5 years, namely the change in open area to a built area and the area built into an open area.
\end{abstract}

Keywords: changed, land, built area, gorontalo

\begin{abstract}
Abstrak - Pembangunan di wilayah perkotaan terus berkembang yang disertai dengan meningkatnya jumlah penduduk. Peningkatan ini berdampak pada semakin tingginya kebutuhan akan ruang kota. Hal ini menyebabkan kawasan terbangun di wilayah perkotaan semakin meningkat dan berkurangnya ruang terbuka sehingga mendorong penggunaan lahan sawah sebagai area permukiman dan perkantoran. Oleh karena itu perlu dilakukan kajian atau evaluasi melalui analisis spasial untuk mengetahui perubahan pemanfaatan lahan sawah yang ada di Kota Gorontalo dalam kurun waktu tertentu. Kajian ini merupakan salah satu acuan dalam arahan pembangunan yang berwawasan lingkungan untuk masa mendatang. Penelitian ini bertujuan untuk menganalisis perubahan pemanfaatan lahan sebagai area terbangun dalam kurun waktu 5 tahun dari tahun 2008 hingga 2013 . Metode yang digunakan dalam penelitian ini adalah analisis spasial terdiri dari data citra dan peta digital sebagai data pendukung. Analisis dilakukan dengan teknik overlay peta penggunaan lahan dengan kurun waktu berbeda hasil interpretasi citra satelit digital. Hasil penelitian menunjukkan terdapat dua jenis perubahan area terbangun di Kota Gorontalo dalam kurun waktu 5 tahun yaitu perubahan area terbuka menjadi area terbangun dan area terbangun menjadi area terbuka.
\end{abstract}

Kata kunci: perubahan, lahan, area terbangun, gorontalo 


\section{PENDAHULUAN}

Pembangunan di wilayah perkotaan terus berkembang yang disertai dengan meningkatnya jumlah penduduk. Peningkatan ini berdampak pada semakin tingginya kebutuhan akan ruang kota. Hal ini menyebabkan kawasan terbangun di wilayah perkotaan semakin meningkat dan berkurangnya ruang terbuka. Secara umum, klasifikasi penggunaan tanah pada kawasan perkotaan dapat dibagi menjadi 7 jenis (Sadyohutomo, 2006), antara lain Perumahan, Perdagangan, Industri, Jasa, Taman, Perairan, Lahan kosong.

Analisis mengenai proses pertumbuhan kawasan terbangun sangat diperlukan untuk menjadi acuan dalam proses perencanaan pembangunan pada suatu wilayah. Kota Gorontalo sebagai ibukota Provinsi Gorontalo merupakan wilayah perkotaan yang mengalami proses pembangunan yang cukup cepat sehingga pemanfaatan lahan untuk bangunan semakin meningkat. Kondisi ini memicu terjadinya perubahan pemanfaatan lahan secara besar-besaran pada kawasan perkotaan.

Kondisi fisik lahan Kota Gorontalo yang pada awalnya merupakan tanah kosong dan persawahan mengalami konversi lahan menjadi perumahan, perkantoran serta perdagangan dan jasa. Kondisi ini memberikan pengaruh terhadap kualitas lingkungan perkotaan dengan berkurangnya daerah resapan air yang mengakibatkan terjadinya banjir dan genangan pada beberapa kawasan. Hal ini sejalan dengan hasil kajian Aprildhani, dkk. (2014), menyatakan bahwa Lahan pertanian dialihfungsikan menjadi lahan terbangun, seperti kawasan perumahan, perdagangan dan jasa serta industri, sehingga kebijakan larangan alih fungsi lahan pertanian irigasi di Kawasan Pertanian Karangploso tidak memberikan dampak bagi implementasi di lapangan. Alih fungsi lahan tidak mungkin dapat dicegah karena kebutuhan akan lahan yang meningkat, namun alih fungsi lahan harus tetap direncanakan agar tidak menimbulkan dampak negatif.

Oleh karena itu perlu dilakukan kajian atau evaluasi melalui analisis spasial untuk mengetahui perubahan pemanfaatan lahan yang terjadi di Kota Gorontalo dalam kurun waktu tertentu. Kajian ini merupakan salah satu acuan dalam arahan pembangunan yang berwawasan lingkungan untuk masa mendatang.

\section{METODE DAN DATA}

Metode yang digunakan dalam penelitian ini adalah metode kuantitatif melalui analisis spasial menggunakan Sistem Informasi Geografis. Analisis data dilakukan dengan melakukan teknik tumpang tindih (overlay) menggunakan peta area terbangun dari Penggunaan Lahan tahun 2008 dan hasil interpretasi citra untuk area terbangun tahun 2018. Data yang digunakan adalah data sekunder yang dianalisis lebih lanjut berdasarkan tujuan penelitian.

\section{HASIL DAN PEMBAHASAN}

Berdasarkan hasil analisis data yang telah dilakukan dengan menggunakan Sistem Informasi Geografis, maka dapat diketahui bahwa luas area terbangun di Kota Gorontalo pada tahun 2008 adalah sebesar 1.564,59 hektar atau sekitar 0,20 persen dari luas total wilayah (Gambar 1). Sedangkan pada tahun 2013 luas area terbangun sebesar 1.641,56 hektar atau sekitar 0,21 persen dari luas wilayah (Gambar 2). Selama periode waktu lima tahun perubahan luas area terbangun di Kota Gorontalo adalah sebesar 76,96 hektar atau mengalami peningkatan sebesar 0,01 persen (Gambar 3). Jumlah ini terlalu besar mengingat beberapa area terbangun pada tahun 2008 juga berubah fungsi menjadi ruang terbuka. Laju perubahan area terbangun di Kota Gorontalo tahun 2008 hingga tahun 2013 jika dirata-ratakan hanya mengalami peningkatan 15,40 hektar per tahun.

Perubahan area terbangun di Kota Gorontalo dalam rentang 5 tahun yaitu dari tahun 2008 hingga tahun 2013 terdiri atas 3 kategori yaitu : 1) Area terbangun yang sama tahun 2008 dan 2013; 2) Area Terbangun dari area terbuka pada tahun 2008; dan 3) Area terbuka yang terbangun pada tahun 2008. Adapun area yang mengalami perubahan dari area terbuka menjadi area terbangun seluas 383,06 hektar sedangkan luas area yang mengalami perubahan dari terbangun menjadi terbuka 305,55 hektar. Peningkatan area terbangun di Kota Gorontalo tahun 2008 hingga 2013 tidak mengalami peningkatan yang signifikan disebabkan luas area yang berubah dari terbangun pada tahun 2008 menjadi area terbuka pada tahun 2013. 


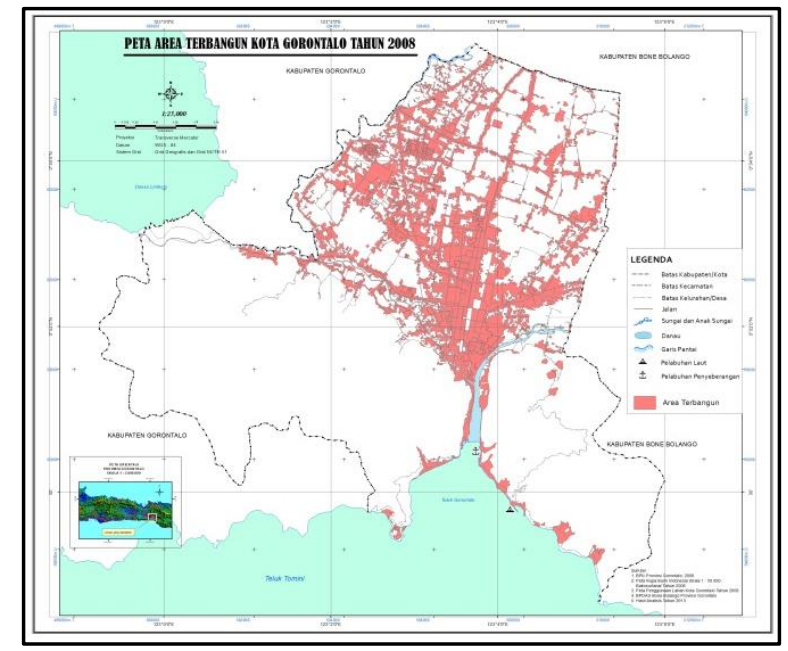

Gambar 1. Peta Area Terbangun Kota Gorontalo Tahun 2008

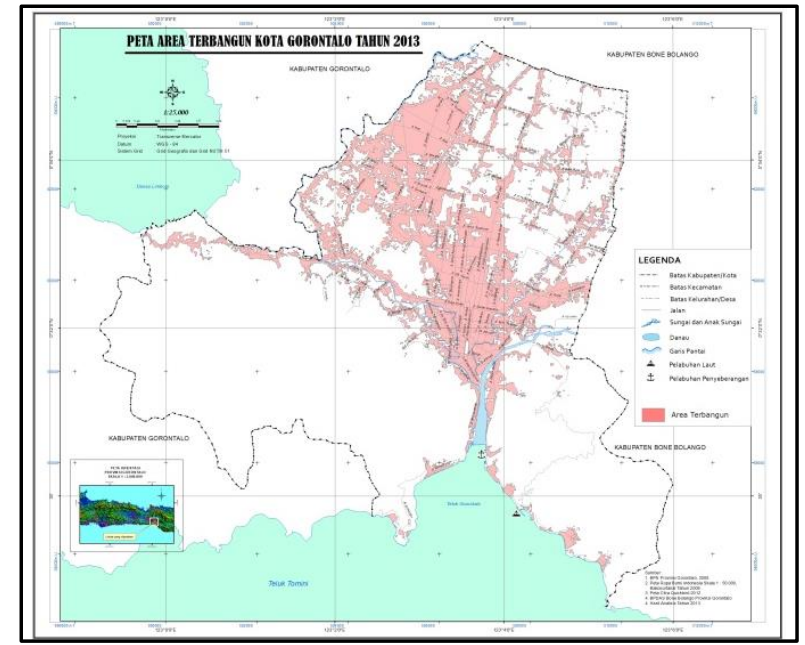

Gambar 2. Peta Area Terbangun Kota Gorontalo Tahun 2013

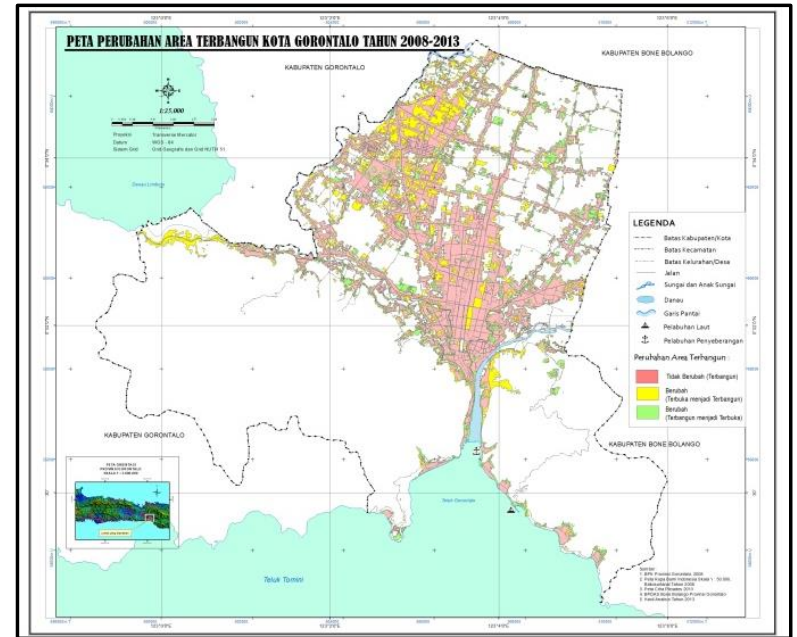

Gambar 3. Peta Perubahan Area Terbangun Kota Gorontalo Tahun 2008 - 2013

Kondisi ini tidak sejalan dengan hasil kajian yang dilakukan oleh Aprildhani, dkk (2014), Purbani (2003) dan Trimarwati (2014) yang menunjukkan bahwa perubahan pemanfaatan lahan khususnya pada kawasan perkotaan cenderung dipicu oleh tingkat kebutuhan akan ruang/lahan yang semakin tinggi seiring dengan semakin meningkatkan proses pembangunan pada suatu 
wilayah. Proses perubahan pemanfaatan lahan dari ruang terbuka menjadi kawasan terbangun dalam berbagai bentuk seperti kawasan permukiman, kawasan industri dan pembangunan infrastruktur seperti jalan dan lainnya.

\section{KESIMPULAN}

Perubahan area terbangun di Kota Gorontalo tahun 2008 hingga tahun 2013 mengalami peningkatan 76,96 hektar atau hanya sekitar 0,01 persen. Hal ini disebabkan oleh luas area terbuka yang berubah menjadi area terbangun hamper sama dengan luas area terbangun menjadi area terbuka sehingga peningkatan luas area terbangun tidak mengalami peningkatan yang cukup signifikan.

\section{DAFTAR PUSTAKA}

Aprildhahani, Hasyim dan Rachmawati, 2014. Alih Fungsi Lahan Pertanian di Kawasan Perkotaan Karangploso Kabupaten Malang Sebagai Dampak Dari Urban Sprawl. Jurnal Pembangunan dan Alam Lestari, Vol. 5 No. 2 Tahun 2014. Universitas Brawijaya, Malang.

Peraturan Menteri Negara Agraria/Kepala Badan Pertanahan Nasional Nomor 1 Tahun 1997

Tentang Pemetaan Penggunaan Tanah Perdesaan, Penggunaan Tanah Perkotaa, Kemampuan Tanah dan Penggunaan Simbol/Warna untuk Penyajian dalam Peta.

Purbani, D., 2003. Perubahan Penggunaan Lahan Persawahan Menjadi Lahan Terbangunan di Kabupaten Karawang. Prosiding Lokakarya Nasional Fakultas Geografi UGM, 30 Agustus 2003.

Sudyohutomo, 2006. Penatagunaan Tanah. Penerbit Aditya Media Yogyakarta.

Trimarwanti, Tessie K.E., 2014. Evaluasi Perubahan Penggunaan Lahan Kecamatan di Daerah Aliran Sungai Cisadane Kabupaten Bogor. Jurnal Pembangunan Wilayah dan Kota Planologi, Vol. 10(1): 43-58 Maret 2014, Universitas Diponegoro. 